\title{
Erratum to: Landscape-Scale Factors Affecting Feral Horse Habitat Use During Summer Within The Rocky Mountain Foothills
}

Tisa L. Girard • Edward W. Bork •

Scott E. Nielsen · Mike J. Alexander

Published online: 24 December 2012

(c) Springer Science+Business Media New York 2012

\section{Erratum to: Environmental Management}

DOI 10.1007/s00267-012-9987-2

Unfortunately, the last name of third author has been misspelled as Neilsen in the online version of this article. The correct spelling is "Scott E. Nielsen".

The online version of the original article can be found under doi:10.1007/s00267-012-9987-2.

T. L. Girard · E. W. Bork $(\bowtie)$

Department of Agricultural, Food and Nutritional Science,

University of Alberta, 410 Agriculture/Forestry Center,

Edmonton, AB T6G 2P5, Canada

e-mail: edward.bork@ualberta.ca

T. L. Girard

e-mail: tlgirard@ualberta.ca

\section{S. E. Nielsen}

Department of Renewable Resources, University of Alberta,

751 General Services Building, Edmonton, AB T6G 2H1,

Canada

e-mail: scottn@ualberta.ca

\section{J. Alexander}

Alberta Environment and Sustainable Resource Development, Lands Division, Pincher Creek, AB, Canada

e-mail: mike.alexander@gov.ab.ca 